Prace Literackie LVII

Wrocław 2017

DOI: $10.19195 / 0079-4767.57 .3$

TOMASZ SAJNÓG

Uniwersytet Wrocławski

\title{
„Mimo tak wielkiej płci naszej zalety, my rządzim światem, a nami kobiety" ". Męski i kobiecy punkt widzenia w poezji oświeceniowej
}

U progu epoki oświecenia w Polsce dominowało przeświadczenie, że twórczość poetycka może być dziełem wyłącznie płci męskiej. Zgodnie z tym kobiecie przypisywano zgoła inne role. Simone de Beauvoir rozważając problem „Inności” kobiet, uznaje, że w tradycyjnym rozumieniu roli kobiety i mężczyzny „mężczyzna jest Podmiotem, jest Absolutem; kobieta jest Innym"2. Kobieta zatem zajmuje miejsce Przedmiotu.

W przypadku literatury oświeceniowej takie twierdzenie może służyć jako doskonały punkt wyjścia, gdyż poeta oświeceniowy wyraża silnie swoją osobowość, której ważnym aspektem jest tożsamość genderowa. Tożsamość ta opiera się na zestawie cech przypisanych kobietom i mężczyznom przez kulturę. W głęboko patriarchalnym społeczeństwie XVIII w. wszelkie naruszenie normy było traktowane jako naganne przez ówczesny system moralny, który sprzyjał męskiej wyższości i dominacji. Kobiecość zaś była skutkiem męskiego apodyktycznego myślenia, wobec którego kobieta musiała godzić się z męskimi (szowinistycznymi) poglądami o jej niższej naturze, nikłym intelekcie oraz z ideą, iż zrealizuje się tylko poprzez role żony i matki, a więc w funkcjach macierzyńsko-rozrodczych. Życie kobiety wydawało się być ograniczone wyłącznie do wypełniania domowych obowiązków.

${ }^{1}$ I. Krasicki, Myszeidos. Pieśni X, p. IV, Warszawa 1775, w. 135-136, s. 41. Powiedzenie to w dobie Krasickiego odnosiło się do kobiet, będących formalnie zależnymi od mężczyzn, które, wykorzystując swą wiedzę, w sposób niezauważalny rządziły światem mężczyzn. Ten stary pogląd, przedstawiający mężczyzn jako bierne narzędzia w rękach demonizowanych kobiet, dziś jest dość powszechnie przyjmowany w dyskursie emancypacyjno-feministycznym. Jego przedstawicielki, w imię potocznie funkcjonującego przekonania, twierdzą, że choć nadal mężczyźni uznawani są za głowę rodziny, to i tak one są jej szyją.

2 S. de Beauvoir, Druga płeć, przeł. G. Mycielska, M. Leśniewska, Warszawa 2009, s. 14. 
Jej powołaniem było wcielanie zakorzenionego przez Kościół i społeczeństwo obrazu żony i matki. Swoim zachowaniem, wiernością wobec bliskich kobieta spełniała wymagania stawiane jej przez honor. Wyrażała siebie w bezustannym poświęcaniu się tym, którzy znajdowali się pod jej dachem, dla których oddawała się cała i bezinteresownie. Jej rolą było służenie i opiekowanie się, co w szerszym kontekście sprowadzało się do wykonywania takich czynności, jak: karmienie, wychowywanie i kształcenie dzieci, pielęgnowanie w chorobie, towarzyszenie przy umieraniu, doglądanie gospodarstwa domowego i dokonywanie wyboru służby. Oprócz skłonności do poświęcenia od kobiety tamtych czasów oczekiwano także tego, aby posiadała takie cnoty, jak skromność czy oszczędność 3 .

Realizowanie wspomnianych czynności i pełnienie różnych obowiązków pozwala odnieść wrażenie, że kobieta miała w gruncie rzeczy dosyć szerokie pole działania w sferze życia prywatnego. Natomiast z życia publicznego na ogół była wykluczona. Nie sprawowała urzędów w polityce, administracji, we władzach miejskich czy handlowych. Bywało jednak, że ta bardziej wykształcona stanowiła siłę doradczą męża piastującego znaczące stanowisko w państwie czy społeczeństwie. Zarysowany w ten sposób wizerunek kobiety pozwala na stwierdzenie, że w owych czasach „zawód” kobiety polegał na absolutnym podporządkowaniu społecznym uwarunkowaniom i mężczyźnie — głowie rodziny. Ten ,podległy status kobiet, ich uzależnienie, bezsilność społeczna i polityczna, nie zostały narzucone przez prawa natury, lecz stanowiły konstrukcję społeczną, polityczną, kulturową, uwarunkowaną historycznie, a więc podlegającą zmianom"4. Od kobiety oczekiwano odpowiedniego zachowania względem otoczenia, podobania się innym, niepopadania w konflikty i bycia „dobrze ułożoną”. Wiązało się to z prawidłowym sposobem poruszania się, stania, mówienia, zachowania się w towarzystwie, opanowaniem savoir vivre'u, dbaniem o estetyczny wygląd i posiadaniem wysokiej kultury osobistej. Zdaniem Sławomiry Walczewskiej, autorki książki Damy, rycerze i feministki, oczekiwania wobec kobiety, wynikające z powszechnie panujących przekonań na jej temat, po raz pierwszy dosyć wyraźnie skodyfikowała na piśmie Klementyna z Tańskich Hoffmanowa w książce Pamiątka po dobrej matce z 1819 r. i kolejnej — O powinnościach kobiet. Nakreśliła w nich szereg wskazówek, podług których kobieta powinna modelować swoje życie ${ }^{5}$. Wszystkie te wyznaczniki i nakazy wobec ówczesnej kobiety i kobiecości całkowicie podporządkowywały ją mężczyźnie, któremu za brak „dobrego ułożenia” nie groziło napiętnowanie społeczne. Płci niewieściej stawiano większe wymagania niż płci męskiej, podobnie jak dostrzegano dużą różnicę w „dobrym wychowaniu" mężczyzn i kobiet. Walczewska nawiązując do książki Hoffmanowej, przytacza zawarty w niej fragment, w którym autorka powołuje się na zawartą

${ }^{3}$ Historia życia prywatnego. Od renesansu do oświecenia, t. 3, red. R. Chartier, przeł. M. Zięba, K. Osińska-Boska, M. Cebo-Foniok, Wrocław-Warszawa-Kraków 1998, s. 431.

${ }^{4}$ M. Bogucka, Gorsza płeć. Kobieta w dziejach Europy od antyku po wiek XXI, Warszawa 2005, s. 8.

5 S. Walczewska, Damy, rycerze i feministki. Kobiecy dyskurs emancypacyjny w Polsce, Kraków 2006, s. 17. 
w Dworzaninie (utwór wydany w 1566 r.) opinię Łukasza Górnickiego na temat różnic pomiędzy płciami. Tenże autor pisał, że

w postawie, w słowach [...], w postępkach ma być białogłowa od mężczyzn różna: bo jako mężczyzna ma to w każdej swojej sprawie pokazywać, iż jest jako dąb, tak zasię w białogłowie ma być coś pieszczonego, w miarę przystojnego żeńskiej niedużości, aby w staniu, w chodzeniu, w mowie i cokolwiek pocznie, nie było w niej znać nic mężczyńskiego ${ }^{6}$.

Słowa Górnickiego, mimo upływu wieków, wyraźnie oddają pozycję niewiasty czasów Hoffmanowej. Podkreślają ich niższą pozycję względem mężczyzn, silnych ,jako dęby”, wobec których kobiety w swej słabości i „niedużości” powinny zachowaniem oraz sposobem bycia podkreślać uniżoną pozycję.

Ten obowiązujący patriarchalny system wartościowania XVIII-wiecznego społeczeństwa oraz zasadniczo męski charakter literatury oświeceniowej i patriarchalna kultura, w której się ona rozwijała, pozwalają uwzględniać w jej badaniach teorie feministyczne. W omawianym okresie pojawiły się pierwsze feministyczne manifesty, które jednak nie odznaczały się szczególnym radykalizmem. Feminizm powszechnie kojarzy się z podejściem przewartościowującym lub skłaniającym do przemyślenia na nowo na dobre zakorzenionych w społeczeństwie wyobrażeń rzeczywistości, zwanych powszechnie stereotypami. Dlatego też teorię i krytykę feministyczną intuicyjnie łączy się z walką z myśleniem stereotypowym. Ich podstawowym zadaniem jest podważanie i kwestionowanie zastanego stanu społecznego światopoglądu.

Zastanawiając się nad genderową tożsamością kobiety w XVIII-wiecznej kulturze androcentrycznej, rozpatrujemy zbiorową tożsamość grupy płci żeńskiej, w skład której wchodzą elementy narzucone z zewnątrz. Tożsamość genderowa składa się z zestawu bardzo konkretnych cech, ról oraz zachowań rezerwowanych dla każdej płci. Oprócz tożsamości genderowej warto doprecyzować tu pojęcie płci kulturowej, które jest wytworem prądu filozoficznego lat 70. XX w. - feministek, głoszących, że gender jest strukturą społeczno-kulturową, odróżniającą to, co męskie, od tego, co żeńskie. W tym sensie gender odzwierciedla płeć biologiczną, ale to nie oznacza, że płeć kulturowa wywodzi się bezpośrednio $\mathrm{z}$ anatomii płciowej. Płeć kulturowa jest bowiem samodzielnym wyznacznikiem kultury, na podstawie którego ustalane są społeczne kategorie kobiety i mężczyzny oraz definiowane stosunki między nimi. Mottem do rozważań na temat płci kulturowej może być pogląd wygłoszony przez S. de Beauvoir już w pierwszej połowie XX w. (1949), mówiący o tym, ,że nikt nie rodzi się kobietą, lecz kobietą się staje"7. Mimo że de Beauvoir napisała to zdanie, gdy jeszcze pojęcie płci kulturowej nie istniało i wbrew temu, że odnosi się tylko do kobiety, ujmuje ono precyzyjnie podstawową ideę genderu — to kultura i relacje społeczne, a nie ana-

\footnotetext{
6 Ibidem, s. 19.

7 S. de Beauvoir, op. cit., s. 11.
} 
tomia czy fizjologia kształtują mężczyznę i kobietę, przypisując im określone role w strukturze każdego społeczeństwa ${ }^{8}$. Dla de Beauvoir stereotypem jest nierówność, ponieważ kobieta może być jak mężczyzna.

Twórczość literacką epoki oświecenia wielokrotnie już przedstawiano w ujęciach syntetycznych, których celem było generalnie wskazanie kierunków rozwojowych, podstawowych dążeń i cech piśmiennictwa, decydujących o swoistym charakterze i odmienności wyodrębnionej przez badaczy epoki. Bogata literatura przedmiotu prezentuje szeroki wachlarz propozycji porządkowania $\mathrm{i}$ interpretowania literatury tego okresu. Ujawnia wielorakie punkty widzenia wobec tak swoistego przedmiotu zainteresowań literaturoznawczych, jaki stanowi zespół dzieł przynależnych wielu autorom powstałych w dość rozległym obszarze czasowym ${ }^{9}$.

Wydaje się przy tym, że intrygująca różnorodność literatury polskiego Oświecenia, szczególnie dobitnie widoczna $\mathrm{w}$ świetle dociekań prowadzonych w tym zakresie w ciągu ostatnich lat, zmusza do poszukiwania pojęć i metod badawczych, które by pozwoliły dostrzec w owej różnorodności elementy wewnętrznego porządku i dokonać rekonstrukcji zasad wyznaczających podobieństwa i różnice konkretnych zespołów zjawisk ${ }^{10}$.

W opinii Kostkiewiczowej to „odległa perspektywa historyczna dzieląca nas od doby stanisławowskiej stwarza szczególnie korzystne, nowe możliwości interpretowania tekstów ówczesnej kultury w kategoriach prądu literackiego". Skoro wieloaspektowe badania literatury oświecenia, o jakich wspomniała Kostkiewiczowa, pomagają w pogłębieniu syntetycznego wizerunku epoki i jej kultury, to może obecnie uzasadnia to potrzebę wykorzystania nowych metodologii badań literaturoznawczych, jakimi są krytyka feministyczna czy społeczno-kulturowe widzenie dorobku literackiego epoki z perspektywy genderowej.

Wiek oświecenia był w dziejach polskiego piśmiennictwa jedynym w swoim rodzaju okresem, w którym można mówić o równowadze liczebnej między piszącymi a czytelnikami. Twórczość wierszowaną uprawiano w różnych okolicznościach i dla różnych celów. W 1777 r. Tomasz Kajetan Węgierski w skierowanej do Ignacego Krasickiego dedykacji poematu Organy pokpiwał z nadmiernej manii „,wierszopistwa”, narzekając na „nawał wierszy, którymi od lat dziesięciu zarzucani jesteśmy". Wówczas dość różnorodnie rozumiano istotę poezji, ale za niezbędne cechy jej twórców uważano twórczy dar i doskonałą wyobraźnię dającą władzę nad językiem, pozwalającą uczynić z wypowiedzi wierszowane dzieło sztuki. Podkreślił to w poemacie O nauce wierszopiskiej w 1762 r. Wacław Rzewuski, pisząc, iż kto nie ma „wierszopiskiego ducha”,

Dla niego Pegaz chromy, muza głucha

I mocne będą Parnasu zapory.

\footnotetext{
8 Ibidem.

9 T. Kostkiewiczowa, Klasycyzm, sentymentalizm, rokoko. Szkice o pradach literackich polskiego Oświecenia, Warszawa 1979, s. 6.

10 Ibidem, s. 10.
} 
Tezy, że poetą trzeba się urodzić, nikt w oświeceniu polskim nie kwestionował, pogląd ten akceptowany był powszechnie ${ }^{11}$. Mimo to niemal każdy, kto interesował się nowościami literackimi, próbował przelać swoje gadulstwo na papier. Był to - jak twierdzi Roman Kaleta — okres pisarstwa masowego i pośpiesznego, co w wielu przypadkach kończyło się swoistą grafomanią wynikającą z braku odpowiednich wzorców w rodzimej twórczości oraz braku wykształconego odbiorcy z wyrobionym smakiem literackim. Zły gust święcił triumfy. Zapał współczesnych do pisania Krasicki porównał z epidemią ospy: „Ta tylko jej od ospy różnica, iż ospa raz odbyta nie wraca się; kakoeta, jak głowę raz opanuje, trwa nieustannie i coraz bardziej dokucza" ${ }^{\prime 2}$. Powszechnej wierszomanii ulegali coraz częściej nie tylko mężczyźni, ale i niewiasty. Jednak nadal w tej obfitości pisarskiej był niewielki odsetek piszących kobiet.

Zasadnym wydaje się postawienie pytania, czy w tak patriarchalnym społeczeństwie, w którym i wśród pisarzy dominowali mężczyźni, twórca piszący o kobietach uwzględniał płeć swoich czytelników, gdy pisał, jak w przypadku omawianego tu utworu, o kobietach-poetkach i kobietach w ogóle. Biorąc pod uwagę pozycję kobiety w ówczesnym społeczeństwie, można przypuszczać, że dla poety było oczywiste, iż przeważającą większością jego czytelników będą mężczyźni. Lecz jeśli nawet poeta kierował swoje utwory do męskiego czytelnika, nie oznacza to, że kobiety ignorowały tę twórczość. Działalność umysłowa kobiet, szczególnie z wyższych warstw społecznych, wskazuje na to, że były one zaznajomione z ówczesną twórczością poetycką. Kobiece pisarstwo, szczególnie uwzględniając analizowany poniżej tekst Anny Chreptowiczowej, stanowi najsilniejszy dowód tego, że wśród czytelników wczesnooświeceniowej poezji znalazły się również kobiety, które zmierzały do zmiany widzenia świata postrzeganego dotąd wyłącznie z perspektywy patriarchalnej dominacji. Oznacza to także, że działalność tradycyjnie należąca do sfery żeńskiej, prywatnej, przypisywanej wyłącznie kobietom, przenosiła się do sfery publicznej, do świata dotychczas zdominowanego przez mężczyzn. Jednakże liczba twórczyń, które mogą być w tej epoce uważane za pisarki, jest wciąż jeszcze bardzo ograniczona.

Włączenie się kobiet do twórczości literackiej nastąpiło w Polsce ze znacznym opóźnieniem — w stosunku do szybciej rozwijających się krajów Europy Zachodniej. Niemałe znacznie dla debiutującej polskiej literatury kobiecej w XVII i XVIII w. miały sławne już wówczas europejskie pisarki, w tym napływ ideałów kulturowych i obyczajowych z francuskich dworów. Spowodowało to falę pierw-

11 Wstęp, [w:] ,'Świat poprawiać - zuchwate rzemiosto”. Antologia poezji polskiego oświecenia, oprac. T. Kostkiewiczowa, Z. Goliński, Warszawa 1981, s. 5.

12 Termin cacoëthes zapożyczył Krasicki od Juvenalisa, a wypowiedź swoją zamieścił w „Monitorze" z 23 września 1772 (nr 77) — zob. R. Kaleta, Miejsce i spoteczna funkcja literatów w okresie oświecenia, [w:] Problemy literatury polskiej okresu oświecenia, red. Z. Goliński, Wrocław 1973, s. 7. W artykule tym zostały opublikowane oba omawiane w niniejszym szkicu utwory. Kaleta ustalił czas ich powstania na początek lat 50 . XVIII w. 
szych prób mniej lub bardziej udanego pisarstwa kobiecego. Jednak nie wszystko, co wtedy się pisało, można było uznać za teksty literackie, tak samo, jak i nie każdą piszącą wówczas kobietę dało się określić mianem pisarki. W Żonie wyćwiczonej Joanna Partyka przekonuje, że nie ma w Polsce w XVI i XVII w. kobiet, które można byłoby nazwać wybitnymi pisarkami i przyrównać je do tych w Europie, piszących już wybitne dzieła. Snuje przypuszczenia, że jest to wynikiem świadomości społeczeństwa polskiego, które nobilitowało pisarzy męskich, dezaprobując w tym względzie kobiety. Twierdzi, że autorów współczesnych traktatów moralizatorskich drażnił wizerunek kobiety z piórem $\mathrm{w}$ dłoni ${ }^{13}$. Wyśmiewali aspiracje żon umiejących czytać i pisać, które robiły z tego jeszcze powszechny użytek. Przez mężczyzn było to postrzegane jako pierwszy krok otwierający kobietom drogę do czytania romansów, zabierania głosu w dyskusji i wyrażania swoich opinii - do buntu przeciwko ustalonym normom. Obawy te nie były jednak w pełni uzasadnione. W Polsce w XVII w. kobiety doświadczone w pisaniu posiadały zakodowane w głębi swojej psychiki poczucie, że ich powinnością jest odgrywanie typowych ról kobiecych, związanych $\mathrm{z}$ byciem matką i żoną ${ }^{14}$. Ten stan rzeczy utrzymywał się przez kolejne stulecia aż po lata współczesne. Obecnie zjawisko kobiecego pisarstwa, dotychczas pomijane wśród badaczy literatury, wywołuje spore zainteresowanie. Karolina Targosz w książce poświęconej sawantkom XVII-wiecznej Polski przywołuje przykłady tekstów niewieściego pióra, o różnej wartości literackiej i pozaliterackiej. Różnorodność i wielość form kobiecego pisarstwa odnajduje w tzw. paraliteraturze, której najpopularniejszymi formami były: epistolografia, kroniczki, „notacyje”, raptularze, pamiętniki z podróży i wreszcie pierwociny poezji ${ }^{15}$. Do docenionych tekstów kobiecego pisarstwa w Rzeczypospolitej autorka zalicza świecki manuskrypt autobiograficzny Małopolanki Anny ze Stanisławskich Zbąskiej ${ }^{16}$. To osobliwe dzieło z 1685 r. uznaje za pierwszą próbę dłuższej formy pisanej wierszem ${ }^{17}$, a autorce przyznaje

13 J. Partyka, Żona wyćwiczona. Kobieta pisząca w kulturze XVI i XVII wieku, Warszawa 2004, s. 28.

14 Eadem, Rewolucja kobiet ominęla Polskę: co wyśmiewat Molier, czyli kwestia kobieca w literaturze, rozm. przepr. K. Lubczyński, „Głos Nauczycielski” 2012, nr 13, s. 5.

15 K. Targosz, Sawantki w Polsce XVII w. Aspiracje intelektualne kobiet ze środowisk dworskich, Warszawa 1997, s. 280.

16 Mowa tu o utworze Transakcyja albo opisanie całego życia jednej sieroty przez żałosne treny od tejże samej pisane roku 1685. Autorka, znając stosunek mężczyzn do intelektualnych praktyk kobiet, zwraca się do czytelnika, nie do czytelniczek, wyjaśniając, iż to dzieło nietypowe i sama rozumie, że może spotkać się z niechęcią męskiego odbiorcy: „Jeśli zaś książka nie do gustu twego, / Ta jej wada, że białogłowskiego / Konceptu, a zaś sama rzecz pisana, / To niech nie będzie od ciebie czytana", cyt. za: K. Targosz, op. cit., s. 281.

17 Jest pokaźnym rękopiśmiennym dziełem w postaci 77 trenów, tj. 745 zwrotek, czyli 5960 wersów zapisanych na 250 stronach - zob. K. Targosz, op. cit. 
tytuł sawantki ${ }^{18}$ XVII-wiecznej Polski, pierwszej świeckiej pisarki podejmującej świecki temat ${ }^{19}$.

W ramach wstępnych rozpoznań do badania twórczości oświeceniowej z perspektywy genderowej omówione zostaną dwa utwory poetyckie przedstawiające zgoła odmienne spojrzenia na twórczość literacką kobiet. Oba powstały jeszcze w czasach saskich, u progu epoki oświecenia.

Wierszopisarstwo kobiet poddał ostrej krytyce Andrzej Chreptowicz, stolnik nowogrodzki, w swego rodzaju manifeście Opisanie powinności i reguły małżenstwu należacej przez Jmć Pana Andrzeja Chreptowicza, młodziana aż do śmier$\mathrm{Ci}^{20}$. Tworzenie literatury uznawał za czynność przypisaną jedynie rodzajowi męskiemu. Nie licząc się z kierunkiem rozwoju światopoglądu kobiet, wygłaszał konserwatywne teorie mówiące o tym, że zabawy kobiet literaturą naruszają zasady i reguły obowiązujące $\mathrm{w}$ małżeństwie, zagrażają rodzinnemu szczęściu i dbałości o gospodarstwo domowe. Przewidywał powszechne popadanie gospodarstw domowych w ruinę i rozliczne kłopoty, zaniechanie przez piszące kobiety codziennych obowiązków względem rodziny, męża czy praktyk religijnych. Wierszopisarstwo kobiet zaburzało jego zdaniem prawa natury, według których kobieta miała przypisane odpowiednie role zarówno w małżeństwie, jak i w społeczeństwie. W dyskryminujących płeć żeńską granicach nie mieściło się przyjmowanie ról wyznaczonych przez naturę wyłącznie płci męskiej. Chreptowicz ograniczył zatem kobiecie możliwość samorealizacji poprzez uprawianie twórczości poetyckiej. W zamian przeznaczył jej rolę gospodyni, której powinnością jest rzetelna praca zapewniająca godne funkcjonowanie domu. Jego postawa precyzyjnie odzwierciedla matrycę potocznej, ale i słownikowej ${ }^{21}$ definicji stereotypu społecznego, według którego rysuje on współczesną mu rzeczywistość w sposób uproszczony, oporny na zmiany oraz fałszujący obiektywny obraz rzeczywistości wczesnooświeceniowej kobiety. Z patriarchalną determinacją obstawał przy swoich antyfeministycznych poglądach, głosząc:

Za tym ksiąg wykład i onych pisanie

Przy męskim ma się utrzymywać stanie.

Tak i oręże mężom wydzielone

Na świątnic Pańskich i granic obronę.

Więc $\mathrm{w}$ takich sprawach już rodzaj niewieści

$\mathrm{Z}$ prawa natury cale się nie mieści...

18 Autorka we wprowadzeniu do swojej książki „sawantkami” nazywa kobiety, które wyróżniały się wówczas intelektualnymi aspiracjami, zdolnościami, takie samo znaczenie miało wtedy określanie ich jako „uczone białogłowy”. W XVII-wiecznej polszczyźnie określenia „kobieta” nie używano ze względu na jego pejoratywny charakter - ibidem, s. 15.

19 Inne niż świeckie pisma tworzone były już wcześniej przez mniszki w klasztorach, tj. kroniki zakonne, biografie wielkich sióstr zakonnych oraz własne mistyczne autobiografie.

20 Jak podaje R. Kaleta, rękopis utworu znajduje się w Centralnej Bibliotece Ukraińskiej Akademii Nauk w Kijowie w Zbiorach ze Szczors, sygn. I 5960, s. 685-687.

21 Zob. Uniwersalny stownik języka polskiego, t. 3, red. S. Dubisz, Warszawa 2003, s. 1391. 
Chreptowicz w swoich stereotypowych uprzedzeniach doszukiwał się hipotez potwierdzających jego obawy przed niechybną ruiną świata zmieniającego się za sprawą rewolucyjnych dążeń kobiet do samorealizacji. Poszukując faktów potwierdzających jego hipotezy, wykazał się swoistą afektywną, jednoznacznie negatywną i w pełni dyskryminacyjną postawą wobec nich. Prorokując niechybne straty majątkowe i zagrożenia dla gospodarstw domowych, przestrzegał przed pozbawionymi męskiej aprobaty działaniami kobiet:

\footnotetext{
Od rannych modlitw co im czasu zbieży,

Niech tego patrzą, co do nich należy,

Bo stąd domowe mitręgi wynikną,

Gdy do pisania różnych ksiąg nawykną

I swą niewieścią całą okolicą

Dom opuściwszy, do wierszów się chwycą.

Na poetyckich bawiąc się wywodach,

Poczynią pustki wielkie po ogrodach;

Nie doglądając i przędzy ochotnie,

Stanie się wielki uszczerbek i płotnie.

Sprzęt przez niedozór wszystek pójdzie marnie

I w nierząd wpadną domowe spiżarnie ${ }^{22}$.
}

Postawa Chreptowicza jest modelowym przykładem emocjonalnej transmisji międzypokoleniowej stereotypów płci dokonującej się w ramach procesu socjalizacji, polegającego na przekazywaniu zestawu wartości, postaw, wiedzy, zachowań $^{23}$ i negatywnych emocji wobec odmiennej płci. Poprzez jego ocenę przedstawionej rzeczywistości przebija przekonanie, że w toku socjalizacji jednostka, w tym przypadku kobieta, powinna zachowywać się zgodnie z tym, czego oczekuje od niej grupa, i przystosować swoje postępowanie do postępowania innych - zgodnie z duchem konformizmu epoki. Wynikać to może z obawy przed destrukcją przyjętych i sprawdzonych w procesie transmisji pokoleniowej reguł patriarchalnego porządku społecznego, opartego na możliwie znanych i przewidywalnych zachowaniach i postawach całego społeczeństwa lub konkretnej klasy społecznej. W opinii Chreptowicza umożliwienie kobietom dostępu do przywilejów należących się wyłącznie mężczyznom naruszyłoby stabilizację hermetycznego świata mężczyzn i zmusiło ich do zaakceptowania nadchodzących zmian. W konsekwencji doprowadziłoby to do zachwiania się męskiego zharmonizowanego świata zinternalizowanych norm, wartości, obyczajów, tradycji i sposobów ich realizacji oraz potrzeby integrowania dwóch systemów normatywnych w jeden wspólny ${ }^{24}$. Autor posłużył się powszechnie stosowanymi stereotypowymi

22 R. Kaleta, op. cit., s. 1.

${ }^{23}$ M. Grabowska, Stereotypy ptci we wczesnej dojrzałości, Bydgoszcz 2007, s. 65.

24 M. Mead takie transmitowanie z pokolenia na pokolenie pewnych elementów kultury nazwałaby dbałością o zachowanie trwałości „tożsamości z pokolenia na pokolenie”. Stało się to podstawą do opracowania koncepcji kultur, w ramach których takie właśnie zjawisko w kulturze zdefiniowała ona jako kulturę postfiguratywną w odróżnieniu od kultury konfiguratywnej oraz pre- 
przekonaniami na temat cech charakterystycznych dla kobiet i mężczyzn, zachowując sztywne, uproszczone wzory zachowań i postaw wobec nich. Mężczyźnie przypisał cechy typowe dla męskiej dominacji, którym jednoznacznie przeciwstawił wzorzec kobiety zależnej od mężczyzny.

W swoich surowych poglądach Chreptowicz godzi się na pisarstwo kobiet będące pod mężowskim nadzorem. Jedyny wyjątek w tym względzie uczynił dla Elżbiety Drużbackiej, uznając jej niepomierny i niepowtarzalny talent. W jego opinii Drużbacka konceptem swojej twórczości górowała nie tylko nad rodzajem żeńskim, ale ze względu na swoje umiejętności poetyckie nie odstawała w niczym od płci męskiej:

\footnotetext{
Ten, co to pisze, każdego przestrzega,

Że tym warunkom cale nie podlega

Wszystkim wiadoma w krainie sarmackiej

Wierszem spisana praca cnej Drużbackiej.

Owszem, tak sądzi, że jej godne skronie

Za styl dowcipny lauru w Helikonie.

Przeto przestaje ksiąg wydania przeczyć,

Bo mogą damy o to mu złorzeczyćc 25 .
}

Doceniony przez Chreptowicza talent Drużbackiej ujawnił się m.in. w doskonale nakreślonym obrazie życia modnych pań nudzących się w towarzystwie swych mężów, nieumiejących zaspokoić pragnień i tęsknot swych małżonek: Skargi kilku dam w spolnej kompanii będacych, dla jakiej racyi z mężami swoimi żyć nie chca. Poetka znając realia czasów, w jakich tworzyła, z wyrazem skromności i uniżoności wobec potencjalnie surowej opinii męskiego czytelnika, z dopraszaniem się o łagodne potraktowanie jej „niewieściej” twórczości, dedykuje mu słowa:

Jeśli w moich wierszach

gustu nie znajdziesz nareszcie,

wybacz, pan dobry,

bo to są... niewieście ${ }^{26}$.

Wśród badaczy literatury okresu oświecenia, czego przykładem zdanie Zdzisława Libery, panuje opinia, że utwory Drużbackiej mają cechy prawdziwej poezji, a ona sama miała wyjątkowo rozwiniętą wyobraźnię i doskonałe umiejętności wersyfikacyjne ${ }^{27}$. Maria Bogucka za twórczość, wiersze pełne artystycznego wdzięku, ogromny wkład do literatury pięknej przyznała jej miano „Sa-

figuratywnej. Dla tej ostatniej koncepcji typowa jest postawa Anny z Chreptowiczów Chreptowiczowej, której wyrazem jest omawiany poniżej tekst (za: M. Mead, Kultura i tożsamość. Studium dystansu międzypokoleniowego, Warszawa 2000, s. 36). Wspomniane koncepcje kultury Mead można by swobodnie odnieść do omawianych tekstów, jednak szczegółowe ich opisanie nie mieści się w ramach tej publikacji.

25 R. Kaleta, op. cit.

26 Cyt. za: S. Walczewska, op. cit., s. 47.

27 Z. Libera, Poezja polska XVIII wieku, Warszawa 1983, s. 15. 
fony polskiej"28. Poetce składali hołd także jej współcześni, sławiąc ją słowem i piórem. Krystyna Stasiewicz — współczesna badaczka dorobku Drużbackiej — uznaje ją za jedną z najpopularniejszych pisarek staropolskich (tzw. literatury czasów saskich - literatury późnego baroku lub, jak niektórzy badacze uważają, wczesnooświeceniowej) ${ }^{29}$. Do dziś postać Drużbackiej jest przedmiotem naukowego zainteresowania. Jej dorobek można uznać za znaczący głos oraz najlepszy przykład stosunku poetki-kobiety do postaw XVIII-wiecznych kobiet. Zarazem jednak trzeba powtórzyć, że w tamtej epoce była jedynie „dozwolonym” wyjątkiem, potwierdzającym regułę generalnej nieobecności kobiet w gronie uznanych publicznie twórców.

W końcowej części manifestu Chreptowicz przestrzega płeć męską przed tym, do czego może doprowadzić wystąpienie kobiet przeciwko obowiązującym prawom natury. Widzi zagrożenie, jakie niesie nadmierne wyzwolenie się kobiet z przyjętych i dotychczas obowiązujących społecznie reguł i norm ustanowionych przez patriarchalny świat. Przestroga dotyczy niebezpieczeństwa nadmiernej emancypacji kobiet. Postawa taka może być także przykładem frustracji i lęku przed dominacją kobiet $\mathrm{w}$ innej niż gospodarstwo domowe sferze życia społecznego. Ze społecznego punktu widzenia uznana byłaby przez współczesne środowiska feministyczne jako przejaw seksizmu wynikającego z negatywnych nastawień, emocji i zachowań wobec kobiet. Kierując się powyższymi obawami, Chreptowicz poddaje mężczyznom pod rozwagę powinności kobiet i reguły należące do małżeństwa:

To jednak wiernie wszystkim mężom radzi,

Co na pamięci chować nie zawadzi,

Żeby nie była żona bez dozoru,

Bo jak mądrego nabierze humoru,

Wraz się wyłamie z posłuszeństwa granic

I będzie męża traktowała za nic.

A w domu barzo już się to źle dzieje,

Gdy kogut milczy, a kura w głos pieje $\mathrm{e}^{30}$.

$\mathrm{Na}$ antyfeministyczny wywód Chreptowicza kontrargumentami zawartymi w Reskrypcie na „Opisanie reguly i powinności matżeńskiej” Jmć Panu Andrzejowi Chreptowiczowi dany przez Jejmć Pania Chreptowiczowa, pisarzowa ziemska grodzieńska ${ }^{31}$ odpowiedziała Anna z Chreptowiczów Chreptowiczowa. Jej utwór, jako przedstawicielki młodego pokolenia, sygnalizuje kiełkowanie nowej świadomości u progu drugiej połowy XVIII w. ${ }^{32}$ Nie jest jeszcze przykładem w pełni

28 M. Bogucka, Kultura, naród, trwanie. Dzieje kultury polskiej od zarania do 1989 roku, Warszawa 2008, s. 218.

${ }^{29}$ K. Stasiewicz, Elżbieta Drużbacka - najwybitniejsza poetka czasów saskich, Olsztyn 1992, s. 10 .

30 R. Kaleta, op. cit.

31 Ibidem, rkps j.w. przyp. 20, s. 688-690.

32 Ibidem, s. 12. 
świadomej walki o równouprawnienie kobiet, ale początkiem rodzącego się nowego spojrzenia na kwestię ich ról społecznych ${ }^{33}$ — nie tylko tych wynikających z natury patriarchalnego świata: żony, matki gospodyni, ale także tych mających służyć rozwojowi intelektualnemu i duchowemu, więc również roli kobiety-poetki. Chreptowiczowa próbuje odnieść się do wszystkich tych ról, które w jej mniemaniu są możliwe do pogodzenia przez parające się pisaniem kobiety. Manifestując swoje stanowisko, wyraźnie odchodzi od myślenia na temat twórczości poetyckiej wyłącznie z męskiego punktu widzenia. W jej poglądach nie dostrzega się jeszcze postawy w pełni ukształtowanej ideowo XIX-wiecznej emancypantki, walczącej przeciwko mężczyznom, upatrującej w nich źródła swej niedoli i poddaństwa. Nie uzurpuje sobie też prawa do zajmowania tych samych stanowisk co mężczyźni, jak chociażby tych, które związane są ze sprawowaniem władzy.

W swoim manifeście Chreptowiczowa przedstawia argumenty przemawiające za lepszym poznaniem faktów oraz przeciwstawia się stereotypowemu męskiemu spojrzeniu na działalność literacką kobiet. W skierowanym do Chreptowicza obszernym proteście zgadza się:

Że w męskie dzieła nie ma się pierzchliwie

Kobieta wdawać i z natury prawa

Miałka, nikczemna ma być jej zabawa ${ }^{34}$.

Jednakże, jeśli idzie o wierszopisarstwo, uznała, że talent ten pochodzi z darów boskich, które jednakowo spływają zarówno na kobiety, jak i na mężczyzn. Wyraźnie przeciwstawia się uproszczeniom, przesadnym uogólnieniom i innym zniekształceniom rzeczywistości, które pomniejszają atrybuty dane kobietom z ręki Boga. Staje w obronie kobiet-literatek, które mają takie samo prawo do tworzenia poezji, głoszenia poglądów na ważne tematy i bycia w jednym szeregu z mężczyznami-literatami.

Przeciwstawiając się tezie postawionej przez Chreptowicza, dowodzi niesprawiedliwości stereotypowego traktowania kobiet. Przytoczone przez niego argumenty uznaje za bezzasadne i fałszujące rzeczywistość, bo nie uwzględniają kobiecego punktu widzenia. Jej spojrzenie na relacje pomiędzy światem kobiet i mężczyzn jest głębsze, bardziej wnikliwe. Pozbawione jest również myślenia i oceniania ludzi według sztywnego wzorca ukształtowanego przez poprzednie pokolenia i powielanego przez kolejne generacje mężczyzn. Poprzez zobrazowanie obu światów, konfrontację obu rzeczywistości Chreptowiczowa stara się zmodyfikować zastaną, spłyconą wiedzę o życiu i powinnościach kobiet. Chce wzbogacić ją o rzeczywiste argumenty oraz przekonać odbiorców do nowe-

33 O zupełnie innych dokonaniach linii żeńskiej Chreptowiczów pisze Łucja Charewiczowa w książce Kobieta w dawnej Polsce (Poznań 2002). Opisuje niejaką Litaworową, wdowę po Janie Litaworze Bogdanowiczu Chreptowiczu, żyjącą na przełomie XV i XVI w. Wspomina ją jako przykład piekielnicy (proceśnicy, herod-baby), która jak wiele jej podobnych z tego okresu sądziła się o każdy skrawek ziemi, co sprzyjało konfliktom rodzinnym, sąsiedzkim lub majątkowym (s. 53).

${ }^{34}$ R. Kaleta, op. cit. 
go spojrzenia na własną grupę - z jednej strony zapracowanych kobiet $\mathrm{w}$ gospodarstwie domowym, a z drugiej tych, które oprócz wysiłku fizycznego włożonego $\mathrm{w}$ prace gospodarcze są zdolne do inwestowania w siebie — za sprawą wysiłku intelektualnego związanego z twórczością literacką:

Chwal tych dowcipów naturalne wdzięki,

Które z Przedwiecznej równie bierzem ręki.

Jeśli zaś mówisz, że w rządach domowych

Znaczny uszczerbek dla zabaw takowych -

Godzina czasu najmniej nie zaszkodzi,

Rozum ogrodom i księgom dogodzi.

A gdy zaś rozum nasz jest stąd zganiony,

Że męski czasem bywa zawstydzony,

Cóżeśmy winne? Czy dla waszej sławy

Bóg swoje mieszać powinien zabawy?

Podobało się Przedwiecznemu Bogu,

By na wysokim nas mądrości progu

Postawił, za czym niźli złorzeczycie,

Nie nas, lecz boskie dzieło w nas ganicie.

Jeśli stąd ganisz tę biegłość w rozumie,

Że żona czasem więcej zna i umie,

Niech się przy miałkiej mądrości nie żeni

Mąż z mądrą, niech wprzód swój rozum oceni.

Nie gań dowcipu, niech w nim obfituje,

Niech tylko cnota jej rozum miarkuje,

Niech się nie chlubi z tego, nie wynosi,

Niech świat, nie ona, jej rozum ogłosi ${ }^{35}$.

Utwór Chreptowiczowej to jakby zapowiedź słów Krasickiego, który w $V I$ Pieśni Myszeidy humorystycznie, a w Panu Podstolim poważnie podkreślił wagę mądrości i zaradności kobiet i ich znaczącego wpływu nie tylko na prawidłowe funkcjonowanie gospodarstw, ale i na losy kraju. Chreptowicz w swoim konserwatyzmie pomija ten aspekt, gdyż zapewne osłabiłoby to ostrość jego argumentacji. Chreptowiczowa tymczasem dodaje, że mąż powinien dostrzec atuty płynące z wiedzy i umiejętności żony. Żeby to uczynić, sam jednak musi być mądry, co można rozumieć i tak, że tylko głupi mężowie zabraniają żonom rozwoju intelektualnego. Głupi więc nie powinni żenić się z mądrymi, co potwierdzić może analiza przykładów przywołanych w tekście. Na ich podstawie można nakreślić światopogląd autorki wiersza. Sama dzięki właściwemu pokierowaniu pracą $\mathrm{w}$ gospodarstwie, pogodzeniu jej z własnymi aspiracjami i wymaganiami stawianymi jej przez patriarchalne społeczeństwo i małżeństwo wypracowała umiejętność swobodnego balansowania pomiędzy obowiązkami i przyjemnościami. Zakłada, że wszystko to, o czym wspomina, jest możliwe do zrealizowania, kiedy spełnione zostaną określone warunki udanego związku. Gwarantem udanego pożycia w małżeństwie, dla kobiety z takimi aspiracjami jak ona, jest posia-

35 Ibidem. 
danie wyrozumiałego i równego jej ideałom mądrego małżonka, doceniającego jej „biegłość w rozumie”, wspierającego ją w urzeczywistnieniu jej pasji. Ten zaś, który z racji swojej „miałkiej mądrości” nie potrafi dostrzec i docenić zalet żony, nie powinien żenić się z mądrą i być w małżeństwie powodem ,gorzkich żali”. Chreptowiczowa wnioskuje zatem, że brak partnerstwa, intelektualnej równości oraz wspierająco-doceniającej się postawy małżonków może doprowadzić do licznych nieporozumień małżeńskich.

Chreptowiczowa dowodzi, że występowanie małżonka przeciwko kreatywności intelektualnej małżonki jest przeciwstawianiem się „boskiemu dziełu”. Jednocześnie uznaje, że pomimo zaszczytnego talentu i wysokiej pozycji otrzymanej od „Przedwiecznego Boga” wyjątkowością kobiety mądrej jest posiadanie „,cnoty”36 niepozwalającej niewieście obdarzonej talentem wierszopisania na przechwalanie się swoimi umiejętnościami. Cnotę dla niej powinna stanowić skromność i cierpliwość oraz pokorne oczekiwanie na docenienie jej umiejętności przez innych, gdyż sama nie powinna chwalić się mądrością.

Niemniej jednak podtrzymuje opinię, że pochopność i powierzchowność oraz afektywność sądów adwersarza stawia kobiety w fałszywym świetle, sama zatem próbuje ukazać rzeczywisty i rzetelny obraz sytuacji ówczesnych niewiast. Wypowiadając się za uznaniem mądrości kobiet i apelując do męskiej próżności, przekracza próg stereotypowych uprzedzeń i społeczno-kulturowych barier. Pomimo szacunku do przeciwnika i uznania myśli zawartych w kwestionowanym przecież utworze, bez nadmiernej nieśmiałości głosi zalety mądrych kobiet:

\footnotetext{
Będzie rząd dobry i niech się kto śmieje,

Że kogut milczy, kura często pieje.

A kto zabrania śpiewać kogutowi?

Mądra mądremu miła jest mężowi.

Te moje zdania nie są tak uporne,

Aby dla ciebie nie były pokorne,

Zacny autorze, i z tym się tu głoszę,

Że twoje myśli nad swoje wynoszę ${ }^{37}$.
}

Powołując się na argument otrzymania twórczych umiejętności z woli Boga, próbuje wpłynąć na zmianę stereotypowego stosunku do piśmiennictwa kobiet. Odwołując się do sankcji religijnej (argument bardzo silny w tamtych czasach), subtelnie wskazuje adwersarzowi inną perspektywę, sugerując, aby zaczął myśleć i oceniać kobiety według innych kategorii. Przełamanie stereotypowych tabu, stanowiących o tym, że rozwój intelektualny jest właściwy wyłącznie płci męskiej, ma zapobiec stratom, jakie powoduje zabranianie kobietom rozwijania ich talentów.

36 Motyw „,cnoty” w XVI-XVIII w. był bardzo popularny w literaturze. W szerszym kontekście rozumieniem cnoty w literaturze w odniesieniu do „cnót małżeńskich” w dobie stanisławowskiej zajmuje się P. Kaczyński, Rodzina w literaturze stanisławowskiej. Motywy — konwencje - poglady, Wrocław 2009, s. 79.

37 Ibidem. 
Tylko nam pozwól zdobyć się w rozumie

I wydać na świat, co z nas każda umie.

A nie każ kopać nam od Boga danych

Talentów w rozum i cnotę przybranych ${ }^{38}$.

Pogląd Chreptowiczowej w sprawie praw kobiet do twórczości literackiej należy potraktować jako jeden z pierwszych w XVIII-wiecznej literaturze przejawów dążeń emancypacyjnych kobiet zmierzających do zmiany trwających wciąż mitów ${ }^{39}$. W rzeczywistości Chreptowiczowej chodzi jednak nie o to, by dążyć do społecznego awansu płci żeńskiej w ogóle, ale o to, by każdemu członkowi społeczeństwa dać równe szanse realizacji własnego modelu szczęścia. Postuluje ona odejście od stereotypowego myślenia o kobiecie i sprzeciwia się istniejącej tradycji, uproszczeniom oraz zmitologizowanemu widzeniu świata. Chodzi także o pokazanie, że kobieta może być równa mężczyźnie, a to znaczy: zdolna do identycznej pracy, twórczości, intelektualnego wysiłku jak mężczyzna.

Tak wysoka świadomość Chreptowiczowej z pewnością wynika z przynależności do klasy ludzi wykształconych. Będąc świadomą swojej roli, przyznaje, że zależy jej na utrzymaniu w dobrym stanie gospodarstwa i budżetu domowego, ale również na dążeniu do rozszerzenia własnych horyzontów myślowych, aktywności intelektualnej i możliwości tworzenia. Jest także świadoma kompromisu, jaki kobietom w jej sytuacji, biegłym w literaturze, przychodzi zawierać pomiędzy wykonywaniem czynności w gospodarstwie domowym a czasem poświęcanym na aktywność intelektualną. Dla własnego rozwoju jest skłonna wziąć na siebie obowiązki we wszystkich sferach życia rodzinnego, łącząc pracę domową z zabawami piórem. Przewiduje, że obie funkcje będzie spełniać jednakowo dobrze i samodzielnie.

Te wszystkie postulaty za sprawą Chreptowiczowej sygnalizują potrzebę nowego podejścia do kwestii kobiet w XVIII-wiecznej Polsce. Problem, jaki podejmuje ta autorka, rozpatrywać można w szerokim kontekście przemian społecznych i kulturowych, które później będą się dokonywały za sprawą sufrażystek walczących o równe prawa. Postulaty Chreptowiczowej to bardzo wczesna zapowiedź tych bojów. Kobiety takie jak Chreptowiczowa, wykształcone, wychowane i żyjące w kręgach inteligencji, nie chciały już być traktowane przedmiotowo. Pragnęły występować nie tylko jako ozdoby swoich domów, w roli gospodyń podczas spotkań towarzyskich.

Zgodnie z tymi postulatami Chreptowiczowa poddaje pod rozwagę zakorzenione w społeczeństwie zasady i przyzwyczajenia dotyczące rozumienia ról płciowych. Wydaje się, że intencją jej było pokazanie, w jaki inny sposób mężczyzna mógłby lub powinien spojrzeć na potrzeby i aspiracje współczesnych mu kobiet. Z jej rozważań wynika jednoznaczna konstatacja, mówiąca o tym, że jeśli mężczyźni dalej będą traktować kobiety w każdej sferze życia zgodnie z utrwalony-

\footnotetext{
38 Ibidem.

39 R. Kaleta, op. cit., s. 12.
} 
mi od dawna regułami, to, pomimo pozorowania obiektywnego podejścia, i tak traktować będą je z „męskim obiektywizmem”. Takie przedmiotowe (subiektywne) traktowanie kobiet wynikało także z obawy, że kobieta zaczynała być coraz częściej postrzegana jako wyraźne zagrożenie dla społecznego ładu opartego na patriarchalizmie. Z tego względu kontynuowano trwającą od stuleci, wzmożoną kontrolę nad nią, czego konsekwencją było regularne wzmacnianie męskiej wyższości. Uważano, że rozwój cywilizacyjny dokonuje się wyłącznie dzięki męskiej dominacji, i wyrażano przeświadczenie, że kobiety swym emocjonalnym temperamentem wprowadzić mogą jedynie chaos i przyczynić się do upadku cywilizacji. Wiersz Chreptowiczowej jest jedną z pierwszych na gruncie polskim prób przeciwstawienia się tym poglądom.

\section{"Despite such great virtues of our sex, we rule the world but we are ruled by women." The male and female points of view in Enlightenment poetry}

Summary

The article, the title of which includes Ignacy Krasicki's aphorism "Despite such great virtues of our sex, we rule the world but we are ruled by women.", deals with a different - from the one assumed by the traditional Enlightenment poetics - view on poetry, seen not only from the male, but also from the female point of view. As part of a preliminary investigation of Enlightenment writings from a gender perspective, the author discusses two poems presenting very different views on literary oeuvres of women.

The analysed texts constitute a contribution to the discussion about the place of women's poetry in the deeply patriarchal society of eighteenth-century Poland. Anna Chreptowicz's piece shows that a woman, in addition to being a wife and a mother - an image firmly rooted in the Church and society - is also capable of writing poetry. She also stands up to the patriarchal moral system of her time, a system that favoured male superiority and domination, as is expressed in the piece by her opponent in the discussion, Andrzej Chreptowicz.

Both eighteenth-century texts presented here demonstrate that in such a patriarchal society, in which writers were predominantly men, there was nevertheless room for poetry written by women, who sought to the change the perception of the world, hitherto seen only from the perspective of patriarchal domination. Anna Chreptowicz's poem is one of the first attempts in Poland to oppose such patriarchal views. 